\title{
Understanding a Two-Sided Coin: Antecedents and Consequences of a Decomposed Product Advantage
}

\author{
Serge A. Rijsdijk, Fred Langerak, and Erik Jan Hultink
}

\begin{tabular}{|l|l|}
\hline \multicolumn{2}{|l|}{ ERIM REPORT SERIES RESEARCH IN MANAGEMENT } \\
\hline ERIM Report Series reference number & ERS-2008-074-ORG \\
\hline Publication & November 2008 \\
\hline Number of pages & 41 \\
\hline Persistent paper URL & http://hdl.handle.net/1765/13833 \\
\hline Email address corresponding author & srijsdijk@rsm.nl \\
\hline Address & Erasmus Research Institute of Management (ERIM) \\
& RSM Erasmus University / Erasmus School of Economics \\
& Erasmus Universiteit Rotterdam \\
& P.O.Box 1738 \\
& 3000 DR Rotterdam, The Netherlands \\
& Phone: + 31 10 408 1182 \\
& Fax: + 31 10 408 9640 \\
& Email: info@erim.eur.nl \\
& Internet: $\quad$ www.erim.eur.nl \\
\hline
\end{tabular}

Bibliographic data and classifications of all the ERIM reports are also available on the ERIM website: www.erim.eur.nl 


\section{RESEARCH IN MANAGEMENT}

\begin{tabular}{|c|c|}
\hline \multicolumn{2}{|c|}{ ABSTRACT AND KEYWORDS } \\
\hline Abstract & 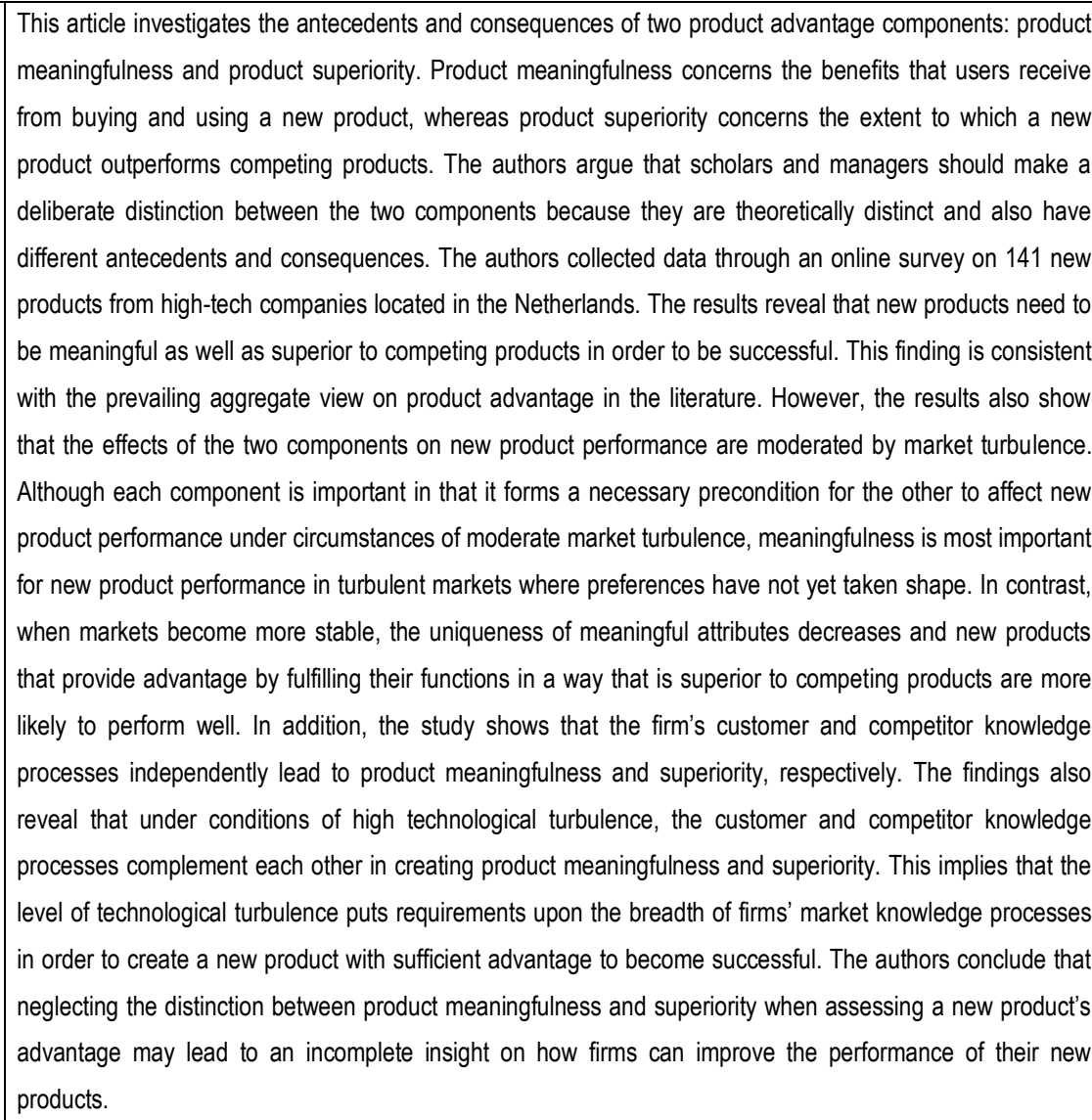 \\
\hline Free Keywords & product meaningfulness, product superiority \\
\hline Availability & $\begin{array}{l}\text { The ERIM Report Series is distributed through the following platforms: } \\
\text { Academic Repository at Erasmus University (DEAR), DEAR ERIM Series Portal } \\
\text { Social Science Research Network (SSRN), SSRN ERIM Series Webpage } \\
\text { Research Papers in Economics (REPEC), REPEC ERIM Series Webpage }\end{array}$ \\
\hline Classifications & $\begin{array}{l}\text { The electronic versions of the papers in the ERIM report Series contain bibliographic metadata } \\
\text { by the following classification systems: } \\
\text { Library of Congress Classification, (LCC) LCC Webpage } \\
\text { Journal of Economic Literature, (JEL), JEL Webpage } \\
\text { ACM Computing Classification System CCS Webpage } \\
\text { Inspec Classification scheme (ICS), ICS Webpage }\end{array}$ \\
\hline
\end{tabular}




\title{
Understanding a Two-Sided Coin:
}

\section{Antecedents and Consequences of a Decomposed Product Advantage}

\author{
Serge A. Rijsdijk ${ }^{i}$ \\ Assistant Professor of Innovation Management \\ Rotterdam School of Management, Erasmus University
}

Fred Langerak

Professor of Product Development and Management

Eindhoven University of Technology

Erik Jan Hultink

Professor of New Product Marketing

Delft University of Technology

This is a preprint of an Article accepted for publication in Journal of Product Innovation Management

(C) 2008 Product Development and Management Association 


\section{Understanding a Two-Sided Coin:}

\section{Antecedents and Consequences of a Decomposed Product Advantage}

\section{Biographical Sketches}

Serge A. Rijsdijk is Assistant Professor of Innovation Management at the Rotterdam School of Management (RSM), Erasmus University in The Netherlands. He received his M.Sc. in industrial and organizational psychology from the Free University of Amsterdam and his Ph.D. from Delft University of Technology. His research interests concern the adoption of smart products, product advantage, and organizational control of new product development projects. He has published his work in such journals as the Journal of the Academy of Marketing Science and in the Journal of Product Innovation Management.

Fred Langerak is Professor of Product Development and Management in the department of Innovation, Technology Entrepreneurship and Marketing of the School of Industrial Engineering at Eindhoven University of Technology, The Netherlands. He has a M.Sc. and Ph.D. from the Erasmus School of Economics. His research focuses on market-driven new product development. He has published on these topics in such journals as International Journal of Research in Marketing, Journal of Product Innovation Management, Journal of Retailing, IEEE Transactions on Engineering Management, R\&D Management, and Industrial Marketing Management.

Erik Jan Hultink is Professor of New Product Marketing at the Faculty of Industrial Design Engineering, Delft University of Technology in The Netherlands. He received his M.Sc. in economics from the University of Amsterdam and his Ph.D. from Delft University of Technology. His research investigates means for measuring and improving the process of new product development and launch. He has published on these topics in such journals as the International Journal of Research in Marketing, Journal of the Academy of Marketing Science, Journal of High Technology Management Research, Industrial Marketing Management, R\&D Management, IEEE Transactions on Engineering Management, and in the Journal of Product Innovation Management. 


\title{
Understanding a Two-Sided Coin:
}

\section{Antecedents and Consequences of a Decomposed Product Advantage}

\begin{abstract}
This article investigates the antecedents and consequences of two product advantage components: product meaningfulness and product superiority. Product meaningfulness concerns the benefits that users receive from buying and using a new product, whereas product superiority concerns the extent to which a new product outperforms competing products. The authors argue that scholars and managers should make a deliberate distinction between the two components because they are theoretically distinct and also have different antecedents and consequences. The authors collected data through an online survey on 141 new products from high-tech companies located in the Netherlands. The results reveal that new products need to be meaningful as well as superior to competing products in order to be successful. This finding is consistent with the prevailing aggregate view on product advantage in the literature. However, the results also show that the effects of the two components on new product performance are moderated by market turbulence. Although each component is important in that it forms a necessary precondition for the other to affect new product performance under circumstances of moderate market turbulence, meaningfulness is most important for new product performance in turbulent markets where preferences have not yet taken shape. In contrast, when markets become more stable, the uniqueness of meaningful attributes decreases and new products that provide advantage by fulfilling their functions in a way that is superior to competing products are more likely to perform well. In addition, the study shows that the firm's customer and competitor knowledge processes independently lead to product meaningfulness and superiority, respectively. The findings also reveal that under conditions of high technological turbulence, the customer and competitor knowledge processes complement each other in creating product meaningfulness and superiority. This implies that the level of technological turbulence puts requirements upon the breadth of firms' market knowledge processes in order to create a new product with sufficient advantage to become successful. The authors conclude that neglecting the distinction between product meaningfulness and superiority when assessing a new product's advantage may lead to an incomplete insight on how firms can improve the performance of their new products.
\end{abstract}




\section{Introduction}

New products with a high level of advantage are developed by firms that have thoughtful and anticipatory market knowledge processes (Atuahene-Gima, 1995; Li and Calantone, 1998). Product advantage concerns the extent to which a new product offers unique benefits and to which it is superior to competing products, and it is considered the most important determinant of new product performance (Henard and Szymanski, 2001). Not surprisingly, product advantage has obtained a central role within the new product development (NPD) literature.

Over time a number of scholars have started to address the nature of the product advantage construct, and its distinction from other important new product constructs such as product innovativeness. For example, Henard and Szymanski (2001) discussed that product advantage is arguably a composite of several distinct product characteristics, such as product meaningfulness and product superiority. In addition, Calantone, Chan, and Cui (2006) mentioned that previous research failed to clearly distinguish product advantage from product innovativeness. In a similar vein, Szymanski, Kroff, and Troy (2007) noted that researchers sometimes inaccurately conceptualized product innovativeness as including a 'meaningfulness' component, which is more related to product advantage than to innovativeness.

It is important to distinguish the constructs of product meaningfulness, product superiority and product innovativeness, as the innovativeness of a new product does not by definition imply that a product is meaningful to customers or superior to competing offerings. Likewise, a product that is meaningful is not necessarily superior to competing products (Szymanski, Kroff, and Troy, 2007). Thus, capturing a product's 
innovativeness, meaningfulness and superiority within a one-dimensional product advantage construct, as is often done in prior studies (see e.g., Langerak, Hultink, and Robben, 2004), may foreclose an effective capturing of the unique role that each construct plays in enhancing new product performance.

While previous studies focused on the delineation of the product innovativeness construct (Calantone, Chan, and Cui, 2006; Szymanski, Kroff, and Troy, 2007), and how it is different from the product advantage construct, no study has yet addressed the distinction between meaningfulness and superiority as separate components of product advantage. The present study fills a part of this gap in the extant literature by deliberately distinguishing between product meaningfulness and product superiority. Product meaningfulness concerns the benefits that customers receive from buying and using a new product, whereas product superiority refers to the extent to which a new product outperforms competing offerings. Figure 1 presents the conceptual model that is developed and tested in this study, and that makes three contributions to the NPD literature.

$<$ Figure 1 about here $>>$

First, investigating product advantage as consisting of two components moves new product research beyond the traditional aggregate conceptualization of product advantage. The authors show that the distinction between product meaningfulness and product superiority is empirically valid, and argue that future research will benefit from considering a two-faceted product advantage approach. In addition, the authors assert that 
a decomposed conceptualization of product advantage helps practitioners as it provides finer-grained guidelines and more actionable ideas on how new products deliver advantage to customers.

Second, this study contributes to the literature by showing that the relationship between product advantage and new product performance may be more intricate than previously thought. The article argues that the importance of the meaningfulness and superiority components to attain new product performance is contingent upon the level of market turbulence. Using dominant design theory (see e.g., Christensen, Suarez, and Utterback, 1998), it is asserted that a highly turbulent market especially calls for new products that are meaningful to customers. However, in markets where a dominant design has emerged and customer preferences are more stable, new products that predominantly provide advantage by being superior to competing products are most successful.

Thirdly, this study shows that product meaningfulness and product superiority are preceded by distinct market knowledge processes; i.e., the customer knowledge process and the competitor knowledge process ( $\mathrm{Li}$ and Calantone, 1998). The customer knowledge process is the key antecedent to product meaningfulness and the competitor knowledge process delivers product superiority. More importantly, the article uses theory on learning in innovation to assert that firms need to have both intense customer and competitor knowledge processes under conditions of high technological turbulence in order to attain product meaningfulness and superiority (Cohen and Levinthal, 1990).

While these findings further stress the relevance of distinguishing between the two components of product advantage, they also provide a perspective on the importance of market knowledge processes in different environmental conditions, which is new to the 
NPD literature. Previous studies (see e.g., Jaworski and Kohli, 1993; Slater and Narver, 1994) argue that technological turbulence negatively moderates the effects of the different market knowledge processes irrespective of the outcome in question. Also, they suggest that market turbulence affects the importance of market knowledge processes as antecedents to performance. Recent meta-analytic findings conclude, however, that there is insufficient evidence for these prevailing views (Kirca, Jayachandran, and Bearden, 2005). For this reason, the study focus on the contingency effects of market and technological turbulence using the dominant design (Christensen, Suarez, and Utterback, 1998) and learning in innovation (Cohen and Levinthal, 1990) perspectives. These perspectives have so far received little attention in explaining new product outcomes.

The remainder of this article is structured as follows. The next section presents the theoretical framework and hypotheses. The research methodology is then presented, followed by a discussion of the results and their implications. The final section discusses limitations and suggestions for further research.

\section{Theoretical Context and Conceptual Framework}

The Distinction between Product Meaningfulness and Product Superiority

Based on the NPD literature, product advantage is defined as the extent to which a new product offers unique benefits and to which it is superior to competing products (Atuahene-Gima, 1995; Calantone and Di Benedetto, 1988; Li and Calantone, 1998). This definition encompasses two distinct components of product advantage: meaningfulness and superiority. Product meaningfulness concerns the extent to which a new product's attributes and functionalities are beneficial to (potential) customers (Im, 
Hussain, and Sengupta, 2008). Thus, meaningfulness can be realized by offering new products that provide new (unique) attributes and functionalities that customers perceive as appropriate, relevant and useful ( $\mathrm{Li}$ and Calantone, 1998). Product superiority refers to the extent to which a new product outperforms competing offerings along existing attributes and functionalities (see also Day and Wensley, 1988). Thus, product superiority can be realized by offering improved performance on the basis of a common ground (Zhou and Nakamoto, 2007).

Prior research has often captured the meaningfulness and superiority components within an aggregate construct of product advantage (Atuahene-Gima, 1995; Li and Calantone, 1998). The underlying rationale can be ascribed to the supposition that both components contribute equally in constituting a new product's advantage. This article considers it important, however, to use a component-wise approach by disaggregating product advantage into its core components because a new product can be meaningful for its users irrespective of how it performs in comparison to competing offerings along existing attributes and functionalities (Szymanski, Kroff, and Troy, 2007). Reasoning the other way round, a new product may outperform existing products on a common ground but not be meaningful for customers because it is superior on attributes or functionalities that customer do not appreciate (Im, Hussain, and Sengupta, 2008). Therefore, product meaningfulness and product superiority are considered to be two distinct components of product advantage that do not necessarily concur. Thus, it is hypothesized:

$\mathrm{H}_{1}$ : Product meaningfulness and product superiority are two distinct components of product advantage. 
The Consequences of Product Meaningfulness and Superiority for New Product

\section{Performance}

New product advantage consistently appears as the most important product characteristic in explaining new product performance (Henard and Szymanski, 2001; Montoya-Weiss and Calantone, 1994; Pattikawa, Verwaal, and Commandeur, 2006). New product performance is defined as the extent to which a new product meets its financial and market goals (Griffin and Page, 1996). Taking a component-wise approach to product advantage implies that one should also examine the effect of the two components of product advantage on new product performance.

It has been argued that the two components of product advantage do not contribute equally to new product performance. Some authors suggest that product meaningfulness is the most important component for new product performance because it represents the extent to which a new product is perceived as appropriate and useful to targeted customers (Narver and Slater, 1990). Henard and Szymanski (2001) provided some evidence for this line of reasoning by showing that the positive performance effect of the extent to which a new product meets customer needs is independent from the extent to which a new product is superior to competing offerings. Others have additionally claimed that the superiority of a new product along existing attributes and functionalities only pays off if the product is also meaningful to customers (Im, Hussain, and Sengupta, 2008). Based on this line of reasoning, it is hypothesized:

$\mathrm{H}_{2 \mathrm{a}}$ : Product meaningfulness is positively associated with new product performance.

$\mathrm{H}_{2 \mathrm{~b}}$ : Product superiority is only positively associated with new product performance 
when product meaningfulness is high (and not when product meaningfulness is low).

\section{The Moderating Effect of Market Turbulence}

Based on dominant design theory, it can be expected that the importance of product meaningfulness and product superiority for new product performance depends on the level of market turbulence. Market turbulence is defined as the rate of change in the composition of customers and their preferences (Hanvanich, Sivakumar, and Hult, 2006). Dominant design theory explains how markets evolve from early turbulent stages into later stages of stability and maturity (Christensen, Suarez, and Utterback, 1998). In the early stages, customer preferences with regard to product attributes are incomplete and it is not yet clear which attributes and functionalities are the most important and best marketable. As a result, the market is characterized by a variety of competing product designs. Overall, the market landscape is unstable and the future of the market is uncertain. However, as the market evolves it becomes more stable and customers start to favor one dominant design over others. This dominant design concerns the specifications that define the product category's architecture. Customer preferences have taken shape and in order to be successful firms need to design their new product's advantage in such a way that its attributes and functionalities match the relatively stable nature of the dominant product design that has emerged (Christensen, Suarez, and Utterback, 1998).

Based on this line of reasoning, it is expected that product meaningfulness is more important when the market is turbulent than when the market is stable. In turbulent markets, a dominant product design has not yet emerged and customers will not restrict 
their purchases to products with specific characteristics. Instead, customers are more likely to choose a product design based on the benefits that it provides. In these turbulent markets, product meaningfulness can be a sufficient condition for success. However, when the market stabilizes and a dominant design emerges, firms' design freedom is reduced and they need to ensure that their new products' attributes and functionalities sufficiently resemble the existing dominant design. Product meaningfulness then becomes a necessary but insufficient condition for success. Meaningful attributes become minimum entry requirements and customers will only consider products with these attributes. As such, previously unique and meaningful attributes become common attributes as market turbulence decreases and they no longer explain the customer's choice among products that share similar attributes. ${ }^{\text {ii }}$ Instead, products that stand out by being superior on these attributes are likely to be most successful and therefore product superiority is expected to be more important in stable markets than in unstable markets. Thus, it is hypothesized:

$\mathrm{H}_{3 \mathrm{a}}$ : The effect of product meaningfulness on new product performance is stronger in turbulent than in stable markets.

$\mathrm{H}_{3 \mathrm{~b}}$ : The effect of product superiority on new product performance is stronger in stable than in turbulent markets.

\section{Market Knowledge Processes as Antecedents to Product Meaningfulness and Superiority}

Several studies have shown that market knowledge processes are important antecedents to product advantage (see e.g., Atuahene-Gima, 1995; Li and Calantone, 1998). Market 
knowledge processes concern the series of activities that generate and integrate market knowledge. Three main processes can be distinguished: a customer knowledge process, a competitor knowledge process, and the marketing-R\&D interface ( $\mathrm{Li}$ and Calantone, 1998). The customer knowledge process refers to the activities that generate knowledge on current and potential customer needs for new products. The competitor knowledge process involves the set of activities that generates knowledge on competitors' products and strategies. The marketing-R\&D interface refers to the process in which marketing and $R \& D$ functions communicate with each other. The marketing- $R \& D$ interface is expected to be important for both product advantage components and is therefore included as a control variable in our study. Our hypotheses focus on the customer and competitor knowledge processes because they are expected to affect product meaningfulness and product superiority differently.

In the customer knowledge process, information on customer needs is acquired through research activities such as focus groups and lead user contacts. This information can be integrated into a new product design by matching product attributes and functionalities with these needs ( $\mathrm{Li}$ and Calantone, 1998). New products that emanate from customer knowledge processes are likely to be compatible with customer needs because the knowledge enables managers to check whether the product attributes and features are indeed beneficial for customers. In addition, knowledge on specific customer needs may initiate the development of new product attributes and functionalities. As such, firms with intense customer knowledge processes are likely to develop new products that deliver a high level of meaningfulness to customers.

The competitor knowledge process generates insights into the strengths and 
weaknesses of a firm and its products compared to rivals ( $\mathrm{Li}$ and Calantone, 1998). These diagnostics enable managers to choose the best moves to defend or improve their products' competitiveness (Day and Wensley, 1988). Competitive knowledge enables a firm to adopt a competitor's strength by imitation or even obliterate the strength of a competing product by launching a new product that is superior along existing attributes and functionalities. As such the competitor knowledge process enables a firm to position the new product as superior to competing offerings within a given market $(\mathrm{Li}$ and Calantone, 1998). Thus, the competitor knowledge process is effective by setting benchmarks through the assessment of competing products, which facilitates the development of a superior product. Thus, it is hypothesized:

$\mathrm{H}_{4 \mathrm{a}}$ : The customer knowledge process is positively associated with product meaningfulness.

$\mathrm{H}_{4 b}$ : The competitor knowledge process is positively associated with product superiority.

\section{The Moderating Effect of Technological Turbulence}

Drawing on the theory of learning in innovation (Cohen and Levinthal, 1990), the authors suggest that technological turbulence requires firms to apply a broader range of market knowledge processes (i.e., both customer and competitor knowledge processes). Technological turbulence is defined as the degree of change associated with product and process technologies in the industry to which a firm supplies (Hanvanich, Sivakumar, and Hult, 2006). Technological instability brings about risk and uncertainty in the NPD process because forecasting becomes more difficult and existing products become 
obsolete within a shorter period of time. Calantone, Garcia, and Dröge (2003) discuss how a firm's ability to recognize the value of market knowledge, to assimilate it, and to exploit it for successful NPD reduces under conditions of rapid technological change. Technological turbulence results in a rise of problems that cannot be easily broken down and dealt with. Cohen and Levinthal (1990) argue that firms can tackle these problems by exposing a broader range of receptors to the market environment. Their line of reasoning suggests that under conditions of high technological turbulence the customer and competitor knowledge processes may complement each other in the creation of product meaningfulness and superiority respectively through two mechanisms. First, the use of multiple knowledge sources implies a broader-ranging search for opportunities which increases the variety of market knowledge and widens the firm's scope ( $\mathrm{Li}$ and Calantone, 1998). As such a firm is more likely to collect the type of knowledge that is required to come up with an appropriate new product response to technological developments that customers perceive as advantageous. Second, the availability of multiple knowledge sources enables firms to validate customer knowledge with competitor knowledge and vice versa (Cohen and Levinthal, 1990). Cross-validation enables firms to better assess the quality of customer and competitor knowledge, and thereby be more effective in exploiting this knowledge in the design of new products with sufficient advantage. Together these arguments suggest that under conditions of high technological turbulence, the competitor knowledge process also contributes to product meaningfulness and the customer knowledge process also adds to product superiority. Thus, the authors hypothesize: 
$\mathrm{H}_{5 \mathrm{a}}$ : The customer knowledge process is only positively associated with product superiority when technological turbulence is high (and not when technological turbulence is low).

$\mathrm{H}_{5 b}$ : The competitor knowledge process is only positively associated with product meaningfulness when technological turbulence is high (and not when technological turbulence is low).

\section{Research Method}

\section{Sample}

The study approached companies in The Netherlands from different industry sectors to ensure sufficient variation in the level of market and technological turbulence. A total of 250 potential respondents from the REACH (Review and Analysis of Companies in Holland) database were contacted of whom 233 agreed to participate in the study. Overall, 149 questionnaires were returned, which results in a response rate of $59.6 \%$. Elimination of eight surveys because of incomplete responses left 141 usable questionnaires. The sample consisted of companies operating in machinery (39.7\%), software and automation (12.8\%), chemicals (11.3\%), audio, video and telecommunications (4.3\%), and other industries (31.9\%). The respondents had a functional background in R\&D (44\%), marketing (22.7\%), sales (14.2\%), general management $(10.6 \%)$, and other backgrounds $(8.5 \%)$. In order to assess potential respondent bias a MANOVA was conducted to check for differences between the various industries and functional backgrounds concerning all independent, control, and dependent variables in our study. The analysis did not reveal any significant differences across the 
different groups of respondents.

\section{Procedure}

Potential respondents were approached by phone to explain the purpose of our study and to ask for their cooperation. Respondents who indicated their willingness to participate in the study received a hyperlink by e-mail to a web-based questionnaire. They were asked to fill out the survey for the most recently introduced product that the respondent was knowledgeable about and for which performance data were available. In order to increase the response rate, a reminder was sent by e-mail to those managers who had not yet responded after fourteen days. Another seven days later a final reminder e-mail was sent to those managers who had not responded by then.

\section{Measures}

This study used subjective data to test the hypotheses for several reasons. First, subjective measures have the advantage of facilitating comparisons across NPD projects of firms from different industries (Atuahene-Gima, 1995). Second, subjective measures have been shown to be correlated to self-reported objective measures of product innovation (see e.g., Ancona and Caldwell, 1992). Third, secondary (i.e., certifiable by a third-party) data were impossible to obtain for some of the constructs (i.e., the customer and competitor knowledge processes). Fourth, subjective measures have often been used in prior studies investigating product advantage and new product performance (e.g., Calantone, Chan, and Cui, 2006; Langerak, Hultink, and Griffin, 2008). 
Main variables. The measures for product meaningfulness and superiority were based on items measuring product advantage in prior studies (e.g., Atuahene-Gima, 1995; Cooper and Kleinschmidt, 1987) as well as newly generated items. The scales initially consisted of four and three items, respectively (see the Appendix). The scales for the customer and competitor knowledge processes were adopted from $\mathrm{Li}$ and Calantone (1998) because these scales are tailored to the use of market knowledge in new product development. The scales consisted of eight and five items, respectively. The measure for market turbulence was adopted from Atuahene-Gima and $\mathrm{Li}$ (2000) and consisted of four items. Technological turbulence was measured with three items based on Calantone, Garcia, and Dröge (2003). The eight items for new product performance were taken from Griffin and Page (1996).

Control variables. The study controlled for innovator type as an antecedent to product meaningfulness and superiority because previous research has shown that business strategy is related to a company's product strategy (Slater, Hult, and Olson, 2007). Respondents were asked to indicate whether their company strategy was that of a technological innovator, fast imitator or cost reducer. In the analysis this variable was represented by a dummy that concerns the category of fast imitators ( 0 , "technological innovator" or "cost reducer", and 1, "fast imitator") and a dummy representing the cost reducers $(0$, "technological innovator" or "fast imitator", and 1, "cost reducer") leaving the technological innovators as the comparison group. The study also controlled for the third market knowledge process, the marketing-R\&D interface, as a possible antecedent to product meaningfulness and superiority. The construct was measured with eight items from $\mathrm{Li}$ and Calantone (1998). The study controlled for customer familiarity as an 
alternative explanation of new product performance (Calantone, Chan, and Cui, 2006). This measure was taken from Atuahene-Gima (1995) and consisted of six items. All multi-item measures used seven-point rating scales where a "1" indicated "completely disagree" and a "7" indicated "completely agree".

\section{Psychometric Properties of the Scales}

Principal components analyses (PCAs) were conducted to obtain initial insights into the dimensionality and underlying structure of the items of each measurement scale. The researchers purified the scales using an eigenvalue of 1.0 and factor loadings of 0.50 as the cut-off points. Next, they performed a series of confirmatory factor analyses (CFAs) to test the scales on their unidimensionality. For each scale, one-factor models were fitted to the data and items that were not unidimensional were dropped until a satisfactory fit was reached. Finally, CFAs were performed on multiple variables simultaneously using LISREL 8.8. Instead of examining all variables in a nine-construct model, two models were fitted for two groups of theoretically interrelated variables to avoid a violation of the five-to-one ratio of sample size to parameter estimates (Bentler and Chou, 1987). Model 1 contained the customer knowledge process, competitor knowledge process, marketingR\&D interface, product meaningfulness, and product superiority constructs. Model 2 contained the market turbulence, technological turbulence, customer familiarity, and new product performance constructs. Both CFA models revealed good fits (see Appendix). The significant factor loadings demonstrated convergent validity, while composite reliabilities (CRs), Cronbach alphas, and average variance extracted (AVE) estimates exceeded the minimum thresholds for all measures except technological turbulence. All 
scales demonstrated adequate discriminant validity by meeting the criterion that the square of the correlation between two constructs should be less than the AVE estimates of both constructs (Fornell and Larcker, 1981). It was also examined whether a one-factor model fitted the data better than a two-factor model for each pair of constructs. In each case, the chi-square of the constrained one-factor model was significantly greater than the chi-square of the two-factor model, also indicating discriminant validity for all constructs.

Potential concerns about common method bias were alleviated by conducting Harman's one-factor test in which all variable items were entered into a single PCA. The results showed that neither a single factor nor a general factor accounted for the majority of the covariance in the items. All the items loaded on separate factors, with all standardized construct loadings above .57. The appendix shows the psychometric properties for all measures, and all items with factor loadings and corresponding t-values. Provided with this evidence of satisfactory psychometric properties the constructs were formed by averaging the responses to all remaining items in a particular scale. Table 1 reports the inter-construct correlations, minimum values, maximum values, means, and standard deviations for all variables.

$<<$ Table 1 about here $>>$

\section{Analysis and Results}

The Distinctiveness of Product Meaningfulness and Product Superiority

Hypothesis 1 concerned the discriminant validity of the product meaningfulness and product superiority components. This hypothesis was tested by fitting two competing 
CFA models to the data on the six remaining items measuring the two advantage components. In the first model, all six items loaded on a single factor and thereby represented the conceptualization in which product meaningfulness and superiority concern a single construct. The fit of this model was not $\operatorname{good}\left(\chi^{2}(9)=243.52\right.$, $\chi^{2} /$ d.f. $=27.06, p$-value $=0.00$, RMSEA $=0.431, \mathrm{GFI}=0.63, \mathrm{NNFI}=0.42$, and $\mathrm{CFI}=0.65$ ). In the second model, each item was allowed to load only on the factor for which it was a proposed indicator and no correlations were permitted in the error structure. The two factors were allowed to covary and the model thereby represents our hypothesized model in which product meaningfulness and superiority are distinct components. The fit of this hypothesized model was good $\left(\chi^{2}(8)=4.29, \chi^{2} /\right.$ d.f. $=0.54$, p-value $=0.83$, RMSEA $=0.000$, $\mathrm{GFI}=0.99, \mathrm{NNFI}=1.01$, and $\mathrm{CFI}=1.00)$ and significantly better than the first model $\left(\Delta \chi^{2}{ }_{(1)}=239.23, \mathrm{p}<.05\right)$. As such, the data supports $\mathrm{H}_{1}$ and shows that product meaningfulness and product superiority are distinct.

The remaining hypotheses were tested by means of three separate hierarchical regression analyses. In these analyses the control variables were entered first, followed by the main effects and the moderating effects. The first order terms were mean-centered before creating the interaction terms (Aiken and West, 1991).

The Effects of Product Meaningfulness and Product Superiority on New Product Performance

Table 2 contains the results of the first regression analyses. Model 2 shows that the main effect of product meaningfulness on new product performance is significant $(\beta=.15$, tvalue $=1.75, \mathrm{p}<.05)$ while the effect of product superiority is not significant. Although 
these results are in line with our expectations, model 3 shows that the effect of the two components on new product performance can be better explained through their joint interaction and their individual interactions with market turbulence.

Model 3 shows that the interaction between product meaningfulness and superiority on performance is significant $(\beta=.14, t$-value $=1.81, \mathrm{p}<.05)$. Post-hoc probing of the simple slopes (Aiken and West, 1991) indicated that the effect of product meaningfulness on new product performance is only significant when product superiority is high (simple slope $=0.28$, S.E. $=0.10, \mathrm{t}$-value $=2.80, \mathrm{p}<.05)$. This finding provides only partial support for $\mathrm{H}_{2 \mathrm{a}}$. Post-hoc probing showed that the effect of product superiority on new product performance is positive and significant (simple slope $=0.24$, S.E. $=0.10, \mathrm{t}$-value $=2.41, \mathrm{p}<.05)$ when product meaningfulness is high, and not significant when meaningfulness is low. This finding provides support for $\mathrm{H}_{2 \mathrm{~b}}$.

The effect of the interactions between product meaningfulness and market turbulence $(\beta=.25, t$-value $=2.77, \mathrm{p}<.05)$, and between product superiority and market turbulence $(\beta=-.14, t$-value $=-1.66, \mathrm{p}<.05)$ on new product performance are both significant. Simple slope tests showed that the effect of product meaningfulness on new product performance is positive and significant when market turbulence is high (simple slope $=0.25$, S.E. $=0.13, \mathrm{t}$-value $=1.89, \mathrm{p}<.05)$ and not significant when market turbulence is low. In contrast, the effect of product superiority on new product performance is not significant when market turbulence is high and positive and significant when market turbulence is low (simple slope $=0.25$, S.E. $=0.13$, t-value $=$ 2.01, $\mathrm{p}<.05)$. These findings provide support for $\mathrm{H}_{3 \mathrm{a}}$ and $\mathrm{H}_{3 \mathrm{~b}}$. 
As a control variable, customer familiarity was negatively related to new product performance $(\beta=-.29, t$-value=-3.74, $\mathrm{p}<.05)$. Furthermore, multicollinearity was not a problem. The maximum variance inflation factor (VIF) score was 1.39 and the maximum condition index was 2.21, both well below the critical cutoff values (Belsley, Kuh, and Welsch, 1980).

As the two-way interactions involving the mean-centered variables of product meaningfulness, product superiority, and market turbulence represent conditional interaction effects, evaluated when the third variable equals zero (Aiken and West, 1991), the findings can be summarized as follows. At a moderate level of market turbulence, both product meaningfulness and product superiority should be high in order to increase new product performance. However, product meaningfulness should be emphasized more when market turbulence is high and product superiority more when market turbulence is low.

The Effects of Market Knowledge Processes on Product Meaningfulness and Product

\section{Superiority}

Table 3 (model 6) shows that the customer knowledge process positively affects product meaningfulness $(\beta=.18, t$-value=1.84, $\mathrm{p}<.05)$, supporting $\mathrm{H}_{4 \mathrm{a}}$. The results (model 9) also show that in support of $\mathrm{H}_{4 \mathrm{~b}}$ the competitor knowledge process has a positive and significant effect on product superiority $(\beta=.21, t$-value $=2.27, \mathrm{p}<.05)$. In addition, the interaction effects between technological turbulence and the competitor knowledge process $(\beta=.20, t$-value $=2.44, \mathrm{p}<.05)$ and the customer knowledge process $(\beta=.18, t$ value $=2.24, \mathrm{p}<.05)$ are positive and significant. Post-hoc probing indicated that the effect 
of the competitor knowledge process on product meaningfulness is significant and positive under circumstances of high technological turbulence (simple slope $=0.32$, S.E. $=0.15, \mathrm{t}$-value $=2.15, \mathrm{p}<.05)$, but not significant when technological turbulence is low. Similarly, the effect of the customer knowledge process on product superiority is significant and positive when technological turbulence is high (simple slope $=0.24$, S.E. $=0.12, \mathrm{t}$-value $=2.00, \mathrm{p}<.05)$ and not significant when technological turbulence is low. Thus, $\mathrm{H}_{5 \mathrm{a}}$ and $\mathrm{H}_{5 \mathrm{~b}}$ are supported implying that firms should have a broad orientation (i.e., customer and competitor orientations) towards the market when technological turbulence is high. While interpreting these latter two findings it needs to be noted that Table 1 shows no positive significant correlations between technological turbulence and the customer and competitor knowledge processes. This would suggest that the breadth of firms' market knowledge processes is not significantly related to technological turbulence. However, our moderated regression results do suggest that those firms that tailor the breadth of their knowledge processes to the level of technological turbulence are more successful in attaining higher levels of product meaningfulness and superiority. One potential explanation for this discrepancy may be that not all firms in our sample put these findings into practice.

As a last point, diagnostic analyses showed that multicollinearity was not a major problem. For model 6 the maximum VIF score was 1.39 and the maximum condition index 13.27. For model 9 the maximum VIF score was 1.53 and the maximum condition index 13.23. Among the control variables in Table 3, the dummies for fast imitator $(\beta=-$ $.20, t$-value $=-2.41, \mathrm{p}<.05)$ and cost reducer $(\beta=.35, t$-value $=-4.34, \mathrm{p}<.05)$ are 
significantly related to product superiority, and the marketing-R\&D interface is significantly related to product meaningfulness $(\beta=.21, t$-value $=2.37, \mathrm{p}<.05)$.

$$
<<\text { Table } 3 \text { about here }>>
$$

\section{Additional Analyses}

It can be argued that technological and market turbulence moderate the effect of the individual components of product advantage on new product performance in a similar manner because they constitute the same construct (e.g., Atuahene-Gima, 1995). To this end model 3 in Table 2 was extended by investigating the moderating effect of technological turbulence on the effects of product meaningfulness and product superiority on new product performance. Neither interaction term was significant however, nor did inclusion of these effects substantially affect the other coefficients in our model. Likewise, other authors have suggested that technological and market turbulence moderate the effect of the individual (i.e., customer and competitor) knowledge processes in a similar vein (Jaworski and Kohli, 1993; Slater and Narver, 1994). To this end, models 6 and 9 were extended by investigating the moderating effect of market turbulence on the effects of the customer and competitor knowledge processes on product meaningfulness and superiority. None of these interactions were significant and inclusion of these effects did not affect the size and significance levels of the other estimates.

\section{Discussion and Implications}

Recently a number of authors have drawn attention to the need for a clearer delineation of 
product-related constructs in the NPD literature (Calantone, Chan, and Cui, 2006; Szymanski, Kroff, and Troy, 2007). Whereas these studies expanded on the product innovativeness construct, our study focused on the antecedents and consequences of two components of product advantage: product meaningfulness and product superiority. Our key results are fourfold. First, product meaningfulness and product superiority need to be considered as two distinct components of product advantage. Second, under circumstances of moderate market turbulence, both components need to have high levels in order for product advantage to affect new product performance. Our expectation that product meaningfulness has a main effect on new product performance was not confirmed. An explanation for this unexpected finding may be that, irrespective of the level of market turbulence, competitive alternatives were available for a substantial number of products in our sample. In the presence of competitive alternatives, product meaningfulness alone is not sufficient for a product to be successful and needs to be combined with product superiority in order to positively affect new product performance. Third, under conditions of high market turbulence, product meaningfulness is more important for new product performance and its importance decreases as markets stabilize. After markets have stabilized, product superiority contributes more strongly to new product performance. Fourth, the two advantage components have different antecedents in that product meaningfulness results from the customer knowledge process while product superiority is preceded by the competitor knowledge process. Only under conditions of high technological turbulence, the customer and competitor knowledge competencies complement each other in contributing to both product meaningfulness and product superiority. 


\section{Theoretical Contributions}

The present study contributes to the NPD literature in three ways. First, the distinction between product meaningfulness and superiority reveals the underlying mechanism of how product advantage affects new product performance. Previous research assumed that this effect could be explained through the fact that customers prefer products that distinguish themselves from other products by an accumulation of various favorable characteristics of equal importance. Our results show that the importance of product meaningfulness and superiority varies. This is an insight that has not yet been recognized. Although each component is important in that it forms a necessary precondition for the other to affect new product performance under circumstances of moderate market turbulence, meaningfulness is most important for new product performance in turbulent markets where preferences have not yet taken shape. In contrast, when markets become more stable, the uniqueness of meaningful attributes decreases and new products that provide advantage by fulfilling their functions in a way that is superior to competing products are more likely to perform well. As such, our results suggest that the theoretical exploration of new product failure should not only be ascribed to the lack of product advantage, as is so far proposed, but also to firms' inability to emphasize the necessary type of advantage (i.e., product meaningfulness or product superiority) that best fits market conditions.

Second, the effects of the customer and competitor knowledge processes on the two product advantage components support previous studies that showed that the two knowledge processes differ in character and that they shape the nature of new products in distinct ways (see e.g., Kahn, 2001; Van Riel, Lemmink, and Ouwersloot, 2004). Our 
results suggest that firms should tailor their market knowledge processes to individual NPD projects. Because market knowledge competencies are difficult to acquire, those firms that are limited in how they emphasize the different knowledge processes will be less successful than those that have a larger repertoire. This may explain the success of market-driven firms that have both strong customer and competitor knowledge capabilities (Day, 1994). These firms can arrange their knowledge processes without restraints and thereby easily match the requirements of different levels of technological turbulence. As such they are better equipped to adjust their market knowledge processes to the necessities of individual NPD projects than firms with a focus on solely customer or competitor knowledge (Day and Nedungadi, 1994).

Third, our study provides a new perspective on the importance to approach market knowledge processes and product advantage at the level of their individual components. Market turbulence puts requirements upon the type of advantage (i.e., meaningfulness or superiority) that a new product should provide in order to be successful. The type of advantage that a firm seeks in new products depends, in turn, on which market knowledge processes a firm employs. Environments that are technologically turbulent require firms to employ a broader range of market knowledge processes than in technologically stable conditions to create products that are meaningful and/or superior. Although these findings oppose existing theory that suggests an attenuating effect of technological turbulence on the usefulness of market knowledge processes (Jaworski and Kohli, 1993; Slater and Narver, 1994), they are in line with existing theory on learning in innovation (Cohen and Levinthal, 1990). Also, these results refine recent research that 
stresses the importance of always having a broad understanding of customers and competitors (De Luca and Atuahene-Gima, 2007).

\section{Managerial Implications}

Our results have two key managerial implications. First, managers should consciously consider two types of advantage that they could pursue in NPD projects to enhance new product performance. Although both product meaningfulness and superiority are important, managers need to emphasize different advantage types depending on market conditions. Volatile markets require an emphasis on the pursuit of product meaningfulness and stable markets ask for an emphasis on superiority. Practitioners that manage to fine-tune their products' advantages to market conditions may deliver new products that are most successful. Second, managers should carefully assess the level of technological turbulence and prioritize their customer and competitor knowledge processes according to the type of advantage that the new product has to deliver. Technologically turbulent environments require knowledge processes related to both customers and competitors. However, managers may narrow their scope when technologies are stable and allocate more resources to the customer knowledge process when striving for product meaningfulness, and accentuate the competitor knowledge process for the development of a product that has to be superior. Prioritizing these knowledge processes enables firms to make efficient use of their limited resources and to take full advantage of their market knowledge capabilities ( $\mathrm{Li}$ and Calantone, 1998). Managers that are unable to take these different resource allocation arrangements into account may weaken their new product's advantage, and ultimately its performance. 


\section{Limitations and Future Research}

This study is limited by several factors that should be addressed in future research. First, this study used data from key informants to test the hypotheses. Therefore the potential for common method bias cannot be discounted, although no bias was found through Harmon's one-factor test. Moreover, common method bias is unlikely to result in significant interaction effects as in this study (Brockner et al., 1997). Future research should nevertheless move towards between-method triangulation to externally validate the results. Second, while this study's causal inferences are grounded in a theoretical framework, causality cannot be inferred from the results reported, as survey research is by nature descriptive rather than prescriptive. Further research might adopt a longitudinal design to address the causality issue. Third, this study used subjective data. Although subjective data often leads to results that are similar to those based on objective data (see e.g., Gotteland and Boulé, 2006) future research is advised to collect, where possible, objective data to replicate the results. Fourth, our scale for technological turbulence did not meet the .50 threshold for AVE and the .70 threshold for CR, suggesting the need for further research to validate the findings related to technological turbulence. Especially our findings suggesting that technological turbulence puts requirements on the breadth of market knowledge processes form an interesting avenue for further research. Fifth, this study only included a limited number of antecedents of a decomposed new product advantage. Future research might expand the set of antecedents with variables such as entrepreneurial proclivity or technological opportunism. Also, taking the level of competitive intensity in the market into account may further clarify the absence of the expected main effect of product meaningfulness on new product performance. 
In conclusion, the present study suggests that the NPD literature should adopt a more refined conceptualization of product advantage by distinguishing between product meaningfulness and product superiority. Future research that incorporates this distinction is likely to generate a better understanding of the role that product advantage plays in enhancing new product performance.

\section{References}

Aiken, Leona S. and West, Stephen G. (1991). Multiple Regression: Testing and Interpreting Interactions. Thousand Oaks, CA, USA: Sage Publications.

Ancona, Deborah G. and Caldwell, David F. (1992). Demography and Design Predictors of New Product Team Performance. Organization Science 3 (3), 321-341 (August).

Atuahene-Gima, Kwaku (1995). An Exploratory Analysis of the Impact of Market Orientation on New Product Performance. A Contingency Approach. Journal of Product Innovation Management 12 (4), 275-293 (September).

Atuahene-Gima, Kwaku and Li, Haiyang (2000). Marketing's Influence Tactics in New Product Development: A Study of High Technology Firms in China. Journal of Product Innovation Management 17 (6), 451-470 (November).

Atuahene-Gima, Kwaku and Li, Haiyang (2002). When Does Trust Matter? Antecedents and Contingent Effects of Supervisee Trust on Performance in Selling New Products in China and the United States. Journal of Marketing 66 (3), 61-81 (July).

Belsley, David A., Kuh, Edwin, and Welsch, Roy E. (1980). Regression Diagnostics: Identifying Influential Data and Sources of Collinearity. New York: John Wiley and Sons.

Bentler, Peter M. and Chou, Chih-Ping (1987). Practical Issues in Structural Modeling. Sociological Methods \& Research 16 (1), 78-117 (August).

Brockner, Joel, Siegel, Phyllis A., Daly, Joseph P., Tyler, Tom, and Martin, Christopher (1997). When Trust Matters: The Moderating Effect of Outcome Favorability. Administrative Science Quarterly 42 (3), 558-583 (September). 
Calantone, Roger, Garcia, Rosanna, and Dröge, Cornelia (2003). The Effects of Environmental Turbulence on New Product Development Strategy Planning. Journal of Product Innovation Management 20 (2), 90-103 (March).

Calantone, Roger J., Chan, Kwong, and Cui, Anna S. (2006). Decomposing Product Innovativeness and Its Effects on New Product Success. Journal of Product Innovation Management 23 (5), 408-421 (September).

Calantone, Roger J. and Di Benedetto, C. Anthony (1988). An Integrative Model of the New Product Development Process: An Empirical Validation. Journal of Product Innovation Management 5, 201-215 (September).

Christensen, Clayton M., Suarez, Fernando F., and Utterback, James M. (1998).

Strategies for Survival in Fast-Changing Industries. Management Science 44 (12), $207-$ 220 (December).

Cohen, Wesley M. and Levinthal, Daniel A. (1990). Absorptive-Capacity - a New Perspective on Learning and Innovation. Administrative Science Quarterly 35 (1), 128 152 (March).

Cooper, Robert G. and Kleinschmidt, Elko J. (1987). New Products: What Separates Winners from Losers? Journal of Product Innovation Management 4 (3), 169-184 (September).

Day, George S. (1994). The Capabilities of Market-Driven Organizations. Journal of Marketing 58 (4), 37-52 (October).

Day, George S. and Nedungadi, Prakash (1994). Managerial Representations of Competitive Advantage. Journal of Marketing 58 (2), 31-44 (April).

Day, George S. and Wensley, Robin (1988). Assessing Advantage: A Framework for Diagnosing Competitive Superiority. Journal of Marketing 52 (2), 1-20 (April).

De Luca, Luigi M. and Atuahene-Gima, Kwaku (2007). Market Knowledge Dimensions and Cross-Functional Collaboration: Examining the Different Routes to Product Innovation Performance. Journal of Marketing 71 (1), 95-112 (January).

Fornell, Claes and Larcker, David F. (1981). Evaluating Structural Equation Models with Unobservable Variables and Measurement Error. Journal of Marketing Research 18 (1), 39-50 (February).

Gotteland, David and Boulé, Jean-Marie (2006). The Market Orientation-New Product Performance Relationship: Redefining the Moderating Role of Environmental Conditions. International Journal of Research in Marketing 23 (2), 171-185 (June). 
Griffin, Abbie and Page, Albert L. (1996). Pdma Succes Measurement Project:

Recommended Measures for Product Development Success and Failure. Journal of Product Innovation Management 13 (6), 478-496 (November).

Hanvanich, Sangphet, Sivakumar, K., and Hult, G. Tomas M. (2006). The Relationship of Learning and Memory with Organizational Performance: The Moderating Role of Turbulence.

Henard, David H. and Szymanski, David M. (2001). Why Some New Products Are More Successful Than Others. Journal of Marketing Research 38 (3), 362-375 (August).

Im, Subin, Hussain, Mahmood, and Sengupta, Sanjit (2008). Testing Interaction Effects of the Dimensions of Market Orientation on Marketing Program Creativity. Journal of Business Research 61 (8), 859-867 (August).

Jaworski, Bernard J. and Kohli, Ajay K. (1993). Market Orientation - Antecedents and Consequences. Journal of Marketing 57 (3), 53-70 (July).

Kahn, Kenneth B. (2001). Market Orientation, Interdepartmental Integration, and Product Development Performance. Journal of Product Innovation Management 18 (5), 314-323 (September).

Kirca, Ahmet H., Jayachandran, Satish, and Bearden, William O. (2005). Market Orientation: A Meta-Analytic Review and Assessment of Its Antecedents and Impact on Performance. Journal of Marketing 69 (2), 24-41 (April).

Langerak, Fred, Hultink, Erik Jan, and Robben, Henry S. J. (2004). The Impact of Market Orientation, Product Advantage, and Launch Proficiency on New Product Performance and Organizational Performance. Journal of Product Innovation Management 21 (2), 7994 (March).

Langerak, Fred, Hultink, Erik Jan, and Griffin, Abbie (2008). Exploring Mediating and Moderating Influences on the Links among Cycle Time, Proficiency in Entry Timing, and New Product Profitability. Journal of Product Innovation Management 25 (4), 370-385 (July).

Li, Tiger and Calantone, Roger J. (1998). The Impact of Market Knowledge Competence on New Product Advantage: Conceptualization and Empirical Examination. Journal of Marketing 62 (4), 13-29 (October).

Montoya-Weiss, Mitzi M. and Calantone, Robert J. (1994). Determinants of New Product Performance: A Review and Meta-Analysis. Journal of Product Innovation Management 11 (5), 397-417 (November).

Narver, John C. and Slater, Stanley F. (1990). The Effect of a Market Orientation on Business Profitability. Journal of Marketing 54 (4), 20-35 (October). 
Pattikawa, Lenny H., Verwaal, Ernst, and Commandeur, Harry R. (2006). Understanding New Product Project Performance. European Journal of Marketing 40 (11-12), 11781193.

Slater, Stanley F., Hult, G. Tomas M., and Olson, Eric M. (2007). On the Importance of Matching Strategic Behavior and Target Market Selection to Business Strategy in HighTech Markets. Journal of the Academy of Marketing Science 35 (1), 5-17 (March).

Slater, Stanley F. and Narver, John C. (1994). Does Competitive Environment Moderate the Market Orientation-Performance Relationship. Journal of Marketing 58 (1), 46-55 (January).

Szymanski, David M., Kroff, Michael W., and Troy, Lisa C. (2007). Innovativeness and New Product Success: Insights from the Cumulative Evidence. Journal of the Academy of Marketing Science 35 (1), 35-52 (March).

Van Riel, Allard C. R., Lemmink, Jos, and Ouwersloot, Hans (2004). High-Technology Service Innovation Success: A Decision-Making Perspective. Journal of Product Innovation Management 21 (5), 348-359 (September).

Zhou, Kevin Z. and Nakamoto, Kent (2007). How Do Enhanced and Unique Features Affect New Product Preference? The Moderating Role of Product Familiarity. Journal of the Academy of Marketing Science 35 (1), 53-62 (March). 


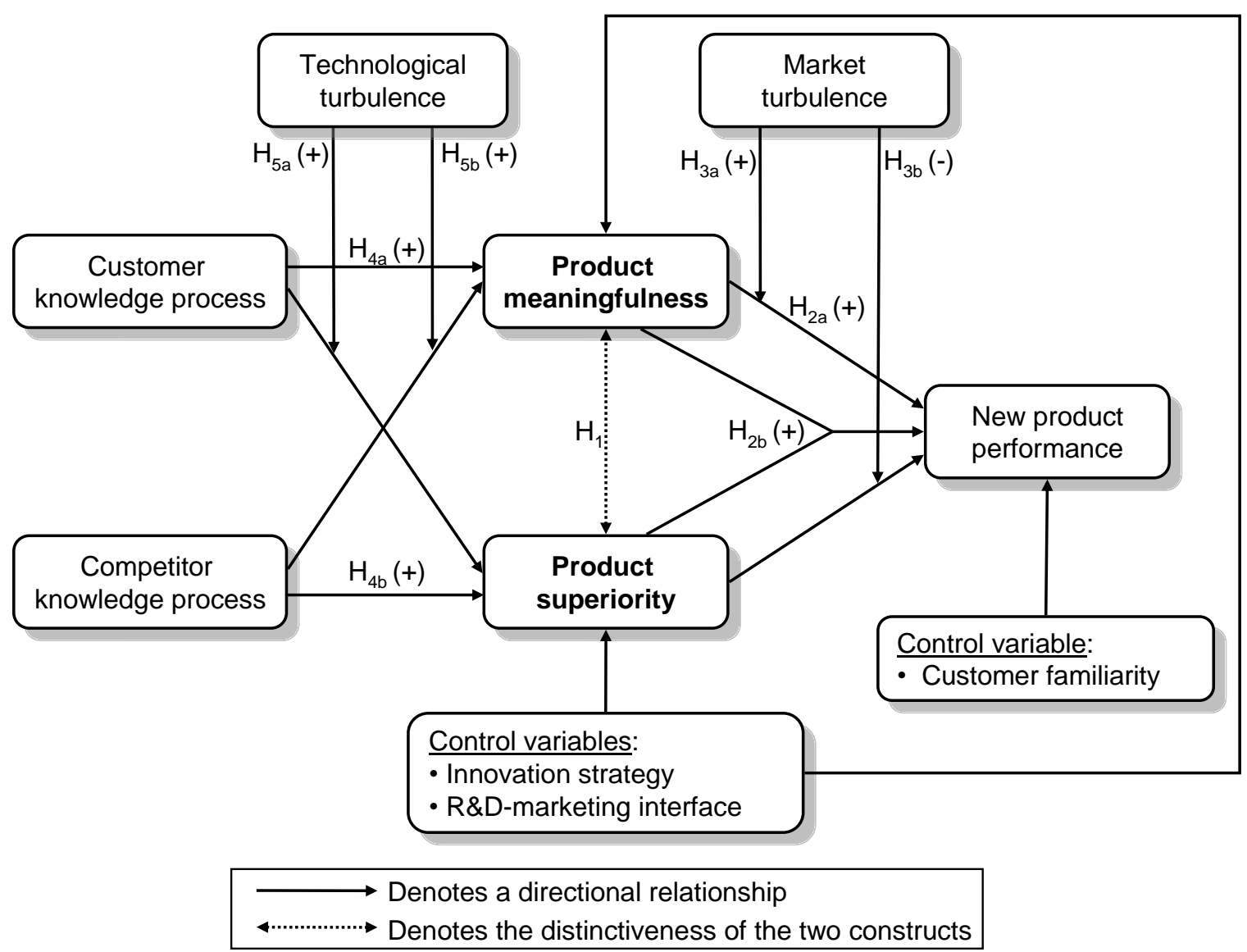

Figure 1 The conceptual framework 
$\underline{\text { Table } 1 \text { Descriptive statistics and correlations }(n=141)}$

\begin{tabular}{|c|c|c|c|c|c|c|c|c|c|c|c|c|c|c|}
\hline & 1 & 2 & 3 & 4 & 5 & 6 & 7 & 8 & 9 & 10 & Min & $\operatorname{Max}$ & Mean & $S D$ \\
\hline 1. Customer knowledge process & - & & & & & & & & & & 1.67 & 7.00 & 5.20 & 0.93 \\
\hline 2. Competitor knowledge process & $.51 *$ & - & & & & & & & & & 2.00 & 7.00 & 4.57 & 1.14 \\
\hline 3. Product meaningfulness & $.26^{*}$ & $.25^{*}$ & - & & & & & & & & 1.00 & 7.00 & 5.26 & 1.21 \\
\hline 4. Product superiority & .13 & $.27 *$ & $.45^{*}$ & - & & & & & & & 3.00 & 7.00 & 5.67 & 0.96 \\
\hline 5. Market turbulence & -.03 & -.08 & -.10 & -.14 & - & & & & & & 1.50 & 7.00 & 3.94 & 1.20 \\
\hline 6. Technological turbulence & .11 & .09 & -.03 & -.05 & $.34 *$ & - & & & & & 1.00 & 7.00 & 3.65 & 1.37 \\
\hline 7. New product performance & .07 & .10 & $.17 *$ & $.18^{*}$ & $-.26^{*}$ & -.09 & - & & & & 1.00 & 7.00 & 4.55 & 1.05 \\
\hline 8. Fast imitator (dummy) & -.14 & -.11 & -.08 & -.10 & -.15 & $-.18 *$ & .07 & - & & & 0.00 & 1.00 & 0.28 & 0.45 \\
\hline 9. Cost reducer (dummy) & .06 & -.05 & -.10 & $-.31 *$ & -.02 & -.05 & .10 & $-.24 *$ & - & & 0.00 & 1.00 & 0.13 & 0.33 \\
\hline 10. Marketing-R\&D interface & $.37 *$ & $.38^{*}$ & $.32 *$ & $.23 *$ & $-.25^{*}$ & .04 & .15 & -.03 & -.14 & - & 1.25 & 7.00 & 4.85 & 1.18 \\
\hline 11. Customer familiarity & .01 & -.04 & .15 & .06 & -.07 & -.06 & $-.25^{*}$ & -.02 & $-.21 *$ & .01 & 1.50 & 7.00 & 5.17 & 1.40 \\
\hline
\end{tabular}

\section{Customer familiarity}

\section{$* p<.05$ (2-tailed).}

All mean entries for the continuous variables are based on a 7-point scale. 
Table 2 Regression results for $\mathrm{H}_{2 \mathrm{a}}-\mathrm{H}_{3 \mathrm{~b}}$

\begin{tabular}{|c|c|c|c|}
\hline \multirow[b]{2}{*}{ Independent variables } & \multicolumn{3}{|c|}{ Dependent variable } \\
\hline & \multicolumn{3}{|c|}{ New product performance } \\
\hline & Model 1 & Model 2 & Model 3 \\
\hline \multicolumn{4}{|l|}{ Control variable } \\
\hline Customer familiarity & $-.25^{*}$ & $-.30 *$ & $-.29 *$ \\
\hline \multicolumn{4}{|l|}{ Main effects } \\
\hline Product meaningfulness & & $.15^{*}$ & .08 \\
\hline Product superiority & & .09 & .12 \\
\hline Market turbulence & & $-.25^{*}$ & $-.24 *$ \\
\hline \multicolumn{4}{|l|}{ Moderating effects } \\
\hline Meaningfulness x Superiority & & & $.14^{*}$ \\
\hline Meaningfulness x Market turbulence & & & $.25^{*}$ \\
\hline Superiority x Market turbulence & & & $-.14^{*}$ \\
\hline$N$ & 141 & 141 & 141 \\
\hline$d f$ of regression model & 1,139 & 4,136 & 7,133 \\
\hline$R^{2}$ & .06 & .18 & .24 \\
\hline Adjusted $R^{2}$ & .06 & .16 & .20 \\
\hline$F$-statistic & $9.56 *$ & $7.67 *$ & $6.03 *$ \\
\hline$R^{2}$ change & & .12 & .06 \\
\hline$F$-change statistic & & $9.56^{*}$ & $3.32 *$ \\
\hline$d f$ of F-change statistic & & 3,136 & 3,133 \\
\hline
\end{tabular}

$* p<.05$.

Note: One-tailed tests were conducted for all hypothesized effects and two-tailed tests for the other effects. 
Table 3 Regression results for $\mathrm{H}_{4 \mathrm{a}}-\mathrm{H}_{5 \mathrm{~b}}$

\begin{tabular}{|c|c|c|c|c|c|c|}
\hline \multirow[b]{2}{*}{ Independent variables } & \multicolumn{6}{|c|}{ Dependent variables } \\
\hline & \multicolumn{3}{|c|}{ Product meaningfulness } & \multicolumn{3}{|c|}{ Product superiority } \\
\hline & Model 4 & Model 5 & Model 6 & Model 7 & Model 8 & Model 9 \\
\hline \multicolumn{7}{|l|}{ Control variables } \\
\hline Fast imitator $^{\mathrm{a}}$ & -.09 & -.08 & -.09 & $-.17^{*}$ & $-.17 *$ & $-.20 *$ \\
\hline Cost reducer ${ }^{b}$ & -.08 & -.10 & -.12 & $-.33^{*}$ & $-.34 *$ & $-.35^{*}$ \\
\hline Marketing-R\&D interface & $.31 *$ & $.22 *$ & $.21 *$ & $.18^{*}$ & .10 & .13 \\
\hline \multicolumn{7}{|l|}{ Main effects } \\
\hline Customer knowledge process & & .13 & $.18^{*}$ & & .00 & .02 \\
\hline Competitor knowledge process & & .10 & .05 & & $.20^{*}$ & $.21 *$ \\
\hline Technological turbulence & & -.08 & -.07 & & -.12 & $-.16^{*}$ \\
\hline \multicolumn{7}{|l|}{ Moderating effects } \\
\hline Customer knowledge process $\mathrm{x}$ Technological turbulence & & & & & & $.18^{*}$ \\
\hline Competitor knowledge process $\mathrm{x}$ Technological turbulence & & & $.20^{*}$ & & & \\
\hline$N$ & 141 & 141 & 141 & 141 & 141 & 141 \\
\hline$d f$ of regression model & 3,137 & 6,134 & 7,133 & 3,137 & 6,134 & 7,133 \\
\hline$R^{2}$ & .11 & .15 & .18 & .16 & .21 & .24 \\
\hline Adjusted $R^{2}$ & .09 & .11 & .14 & .14 & .17 & .20 \\
\hline$F$-statistic & $5.83 *$ & $3.87 *$ & $4.29 *$ & $8.65^{*}$ & $5.81 *$ & $5.85^{*}$ \\
\hline$R^{2}$ change & & .03 & .04 & & .05 & .03 \\
\hline$F$-change statistic & & 1.81 & $5.96 *$ & & $3.46^{*}$ & $2.65 *$ \\
\hline$d f$ of F-change statistic & & 3,134 & 1,133 & & 3,134 & 1,133 \\
\hline
\end{tabular}


Appendix Measures, corresponding factor loadings and t-values, and psychometric properties

\begin{tabular}{|c|c|c|c|}
\hline \multirow{2}{*}{$\begin{array}{l}\text { Model } 1 \\
\text { Construct and Source }\end{array}$} & \multicolumn{3}{|c|}{$\begin{array}{l}\text { Model Fit Indexes: } \chi_{(160)}^{2}=231.60 ; \chi^{2} / \text { d.f. }=1.45 ; \text { RMSEA }=0.06 ; \mathrm{GFI}=0.86 \text {; } \\
\text { NNFI }=0.97 ; \text { CFI }=0.97\end{array}$} \\
\hline & Items & $\begin{array}{l}\text { Factor } \\
\text { Loadings }\end{array}$ & $\begin{array}{l}\mathrm{t}- \\
\text { values }\end{array}$ \\
\hline $\begin{array}{l}\text { Customer knowledge } \\
\text { process }^{1}\end{array}$ & $\begin{array}{l}(\alpha=.75 \mathrm{CR}=.76 \mathrm{AVE}=.51) \\
(1=\text { 'strongly disagree' and } 7=\text { 'strongly agree') }\end{array}$ & & \\
\hline \multirow[t]{8}{*}{$\begin{array}{l}\text { (adopted from Li and } \\
\text { Calantone, 1998) }\end{array}$} & $\begin{array}{l}\text { 1. We regularly meet customers to learn their } \\
\text { current and potential needs for new products }\end{array}$ & .64 & 9.28 \\
\hline & 2. Our knowledge of customer needs is thorough & .83 & 9.12 \\
\hline & We fully understand our customers' business & .66 & 9.28 \\
\hline & $\begin{array}{l}\text { 4. We regularly use research procedures, e.g. } \\
\text { personal interviews, focus groups, and surveys, to } \\
\text { gather customer information }{ }^{2}\end{array}$ & & \\
\hline & $\begin{array}{l}\text { 5. We systematically process and analyze customer } \\
\text { information }^{2}\end{array}$ & & \\
\hline & $\begin{array}{l}\text { 6. Customer information is fully integrated in new } \\
\text { product design }\end{array}$ & & \\
\hline & $\begin{array}{l}\text { 7. We regularly use customers to test and evaluate } \\
\text { new products }\end{array}$ & & \\
\hline & $\begin{array}{l}\text { 8. We regularly study customers' operations for new } \\
\text { product development }^{2}\end{array}$ & & \\
\hline $\begin{array}{l}\text { Competitor knowledge } \\
\text { process }\end{array}$ & \multicolumn{3}{|l|}{$\begin{array}{l}(\alpha=.90 \mathrm{CR}=.90 \mathrm{AVE}=.64) \\
(1=\text { 'strongly disagree' and } 7=\text { 'strongly agree') }\end{array}$} \\
\hline \multirow[t]{5}{*}{$\begin{array}{l}\text { (adopted from } \mathrm{Li} \text { and } \\
\text { Calantone, 1998) }\end{array}$} & $\begin{array}{l}\text { 1. We regularly search and collect information } \\
\text { about our competitors' products and strategies }\end{array}$ & .81 & 11.21 \\
\hline & $\begin{array}{l}\text { 2. We systematically analyze information about } \\
\text { competitors }\end{array}$ & .82 & 11.45 \\
\hline & $\begin{array}{l}\text { 3. Information about competitors' products is fully } \\
\text { integrated as a benchmark in our product design }\end{array}$ & .81 & 11.32 \\
\hline & $\begin{array}{l}\text { 4. Our knowledge of our competitors' strengths and } \\
\text { weaknesses is thorough }\end{array}$ & .75 & 9.97 \\
\hline & We regularly study our competitors' products & .82 & 11.50 \\
\hline \multirow{9}{*}{$\begin{array}{l}\text { Marketing-R\&D interface } \\
\text { (adopted from } \mathrm{Li} \text { and } \\
\text { Calantone, 1998) }\end{array}$} & \multicolumn{3}{|l|}{$(\alpha=.91 \mathrm{CR}=.91 \mathrm{AVE}=.63)$} \\
\hline & $\begin{array}{l}\text { 1. Marketing and R\&D regularly share information } \\
\text { on customers }\end{array}$ & .71 & 9.33 \\
\hline & $\begin{array}{l}\text { 2. Marketing and R\&D fully cooperate in } \\
\text { establishing new product development goals and } \\
\text { priorities }\end{array}$ & .80 & 11.21 \\
\hline & $\begin{array}{l}\text { 3. Marketing and R\&D fully cooperate in } \\
\text { generating and screening new product ideas and } \\
\text { testing concepts }\end{array}$ & .83 & 11.79 \\
\hline & $\begin{array}{l}\text { 4. Marketing and R\&D fully cooperate in } \\
\text { evaluating and refining new products }\end{array}$ & .88 & 12.80 \\
\hline & $\begin{array}{l}\text { 5. Marketing and R\&D are fully represented on our } \\
\text { product development team }\end{array}$ & .75 & 10.21 \\
\hline & $\begin{array}{l}\text { 6. Technological knowledge and market knowledge } \\
\text { are fully integrated in our new product } \\
\text { development }\end{array}$ & .78 & 10.73 \\
\hline & $\begin{array}{l}\text { 7. Marketing and R\&D regularly communicate for } \\
\text { new product development }\end{array}$ & & \\
\hline & $\begin{array}{l}\text { 8. Marketing and R\&D regularly share information } \\
\text { about competitors' products and strategies }{ }^{2}\end{array}$ & & \\
\hline
\end{tabular}


Appendix (continued)

\begin{tabular}{|c|c|c|c|}
\hline \multirow{2}{*}{$\begin{array}{l}\text { Model } 1 \\
\text { Construct and Source }\end{array}$} & \multicolumn{3}{|c|}{$\begin{array}{l}\text { Model Fit Indexes: } \chi^{2}(160)=231.60 ; \chi^{2} / \text { d.f. }=1.45 ; \text { RMSEA }=0.06 ; \mathrm{GFI}= \\
0.86 ; \mathrm{NNFI}=0.97 ; \mathrm{CFI}=0.97\end{array}$} \\
\hline & Items & $\begin{array}{l}\text { Factor } \\
\text { Loadings }\end{array}$ & $\begin{array}{l}\mathrm{t}- \\
\text { values }\end{array}$ \\
\hline \multirow{4}{*}{$\begin{array}{l}\text { Product meaningfulness }^{1} \\
\text { (based on Atuahene- } \\
\text { Gima, 1995; Cooper and } \\
\text { Kleinschmidt, 1987) }\end{array}$} & \multicolumn{3}{|l|}{$\begin{array}{l}(\alpha=.92 \mathrm{CR}=.92 \mathrm{AVE}=.79) \\
(1=\text { 'strongly disagree' and } 7=\text { 'strongly agree' })\end{array}$} \\
\hline & $\begin{array}{l}\text { 1. The new product provides many benefits to the } \\
\text { customer }\end{array}$ & .94 & 14.27 \\
\hline & $\begin{array}{l}\text { 2. The new product offers much value to the } \\
\text { customer }\end{array}$ & .85 & 14.13 \\
\hline & $\begin{array}{l}\text { 3. The new product offers many advantages } \\
\text { 4. The new product offers a lot of value }{ }^{2}\end{array}$ & .87 & 14.13 \\
\hline \multirow{4}{*}{$\begin{array}{l}\text { Product superiority }{ }^{1} \\
\text { (based on Atuahene- } \\
\text { Gima, 1995; Cooper and } \\
\text { Kleinschmidt, 1987) }\end{array}$} & \multicolumn{3}{|l|}{$\begin{array}{l}(\alpha=.91 \mathrm{CR}=.91 \mathrm{AVE}=.78) \\
(1=\text { 'strongly disagree' and } 7=\text { 'strongly agree') }\end{array}$} \\
\hline & $\begin{array}{l}\text { 1. The new product is superior to competing } \\
\text { products }\end{array}$ & products & 13.71 \\
\hline & $\begin{array}{l}\text { 2. The new product is the best of its kind in the } \\
\text { market }\end{array}$ & .96 & 14.85 \\
\hline & 3. The new product is superior in its category & .84 & 13.71 \\
\hline Model 2 & \multicolumn{3}{|c|}{$\begin{array}{l}\text { Model Fit Indexes: } \chi^{2}(99)=109.35 ; \chi^{2} / \text { d.f. }=1.10 ; \text { RMSEA }=0.03 ; \text { GFI }=0.91 ; \\
\text { NNFI }=0.99 ; \mathrm{CFI}=0.99\end{array}$} \\
\hline \multirow{7}{*}{$\begin{array}{l}\text { Customer familiarity } \\
\text { (adopted from Atuahene- } \\
\text { Gima, 1995) }\end{array}$} & \multicolumn{3}{|l|}{$(\alpha=.80 \mathrm{CR}=.87 \mathrm{AVE}=.64)$} \\
\hline & $\begin{array}{l}\text { 1. The product required a major learning effort by } \\
\text { the customers }\end{array}$ & .74 & 9.95 \\
\hline & $\begin{array}{l}\text { 2. It took a long time before customers could } \\
\text { understand the product's full advantages }\end{array}$ & .89 & 12.90 \\
\hline & $\begin{array}{l}\text { 3. The product concept was difficult for customers } \\
\text { to evaluate or understand }\end{array}$ & .94 & 14.04 \\
\hline & $\begin{array}{l}\text { 4. The product was more complex than what we } \\
\text { have introduced before in the same market }\end{array}$ & .57 & 7.06 \\
\hline & $\begin{array}{l}\text { 5. The product involved high changeover costs for } \\
\text { the customer }\end{array}$ & & \\
\hline & $\begin{array}{l}\text { 6. The product required considerable advance } \\
\text { planning by customers before use }{ }^{2}\end{array}$ & & \\
\hline \multirow{5}{*}{$\begin{array}{l}\text { Market turbulence } \\
\text { (adopted from Atuahene- } \\
\text { Gima and Li, 2002) }\end{array}$} & \\
\hline & $\begin{array}{l}\text { ( } 1=\text { 'strongly agree' and } 7=\text { 'strongly disagree') } \\
1 . \quad \text { The market of the new product is stable }\end{array}$ & 68 & 8.58 \\
\hline & The market of the new product is certain & .86 & 11.46 \\
\hline & The market of the new product is predictable & .83 & 10.93 \\
\hline & The market of the new product changes slowly & .53 & 6.25 \\
\hline
\end{tabular}




\section{Appendix (continued)}

\begin{tabular}{|c|c|c|c|}
\hline Model 2 & $\begin{array}{l}\text { Model Fit Indexes: } \chi_{(99)}^{2}=109.35 ; \chi^{2} / \text { d.f. }=1.10 ; \text { RMS } \\
\text { NNFI }=0.99 ; \text { CFI }=0.99\end{array}$ & $=0.03$ & 0.91; \\
\hline \multirow{2}{*}{$\begin{array}{l}\text { Construct and Source } \\
\text { Technological turbulence } \\
\text { (based on Calantone, } \\
\text { Garcia, and Dröge, 2003) }\end{array}$} & Items & $\begin{array}{c}\text { Factor } \\
\text { Loadings }\end{array}$ & $\begin{array}{l}\mathrm{t}- \\
\text { values }\end{array}$ \\
\hline & $\begin{array}{l}(\alpha=.64 \mathrm{CR}=.65 \mathrm{AVE}=.39) \\
1 . \quad \text { The rate of new product introduction instigated } \\
\text { by competitors is (1="less than one year", } 7=\text { "7 } \\
\text { years or more") })^{3}\end{array}$ & 0.59 & 6.87 \\
\hline & $\begin{array}{l}\text { 2. Products become obsolete (out of date) in this } \\
\text { market within (1="less than one year", } 7=\text { "7 years } \\
\text { or more") } \\
\text { 3. The rate of technology change in this market is } \\
\text { (1= "slow", } 7=\text { "fast") }\end{array}$ & 0.74 & 6.24 \\
\hline $\begin{array}{l}\text { New product performance } \\
\text { (adopted from Griffin and } \\
\text { Page, 1996) }\end{array}$ & 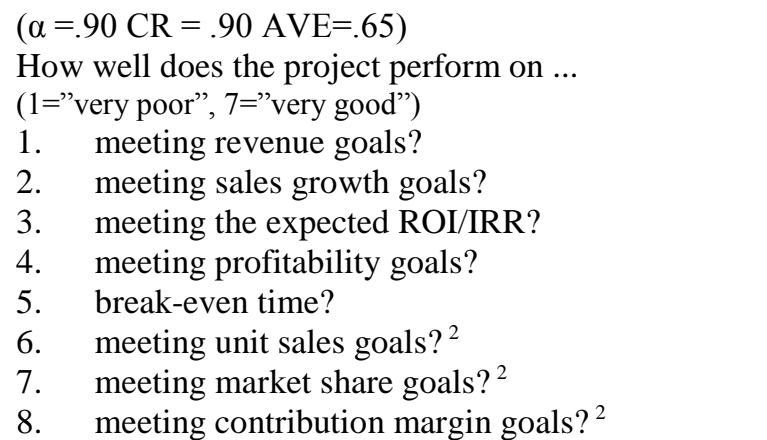 & $\begin{array}{l}.81 \\
.71 \\
.85 \\
.86 \\
.78\end{array}$ & $\begin{array}{c}11.26 \\
9.31 \\
12.06 \\
12.44 \\
10.68\end{array}$ \\
\hline
\end{tabular}

\footnotetext{
${ }^{1}$ For the 3-item scales, two of the loadings were specified to be equal to enable testing of the CFA models; this is because a one-factor, three indictor CFA model is just-identified and has zero degrees of freedom.

${ }^{2}$ Items were dropped from the scale during the measure purification phase.

${ }^{3}$ Item is reversely coded.
} 
${ }^{\mathrm{i}}$ Corresponding author: Serge A. Rijsdijk, Rotterdam School of Management, Erasmus University, P.O. Box 1738, 3000 DR Rotterdam, The Netherlands. Tel.: +31 10408 2541. Fax: +31 10408 9014. E-mail: srijsdijk@ @rsm.nl.

The authors would like to thank the editor and reviewers for their comments on previous versions of this manuscript. They also appreciate the comments of seminar participants at the Rotterdam School of Management and the Aston Business School. This article also benefited from comments by Vera Blazevic, Nukhet Harmancioglu, Lenny Pattikawa, Stefano Puntoni, and Peter Verhoef. An earlier version of this article received the PDMA Research Forum Best Paper Award in 2006.

ii This articulate line of reasoning was offered by one of the reviewers. 


\section{Publications in the ERIM Report Series Research* in Management}

\section{ERIM Research Program: "Organizing for Performance"}

2008

Explaining Preferences and Actual Involvement in Self-Employment: New Insights into the Role of Gender Ingrid Verheul, Roy Thurik and Isabel Grilo ERS-2008-003-ORG

http://hdl.handle.net/1765/10979

Public Finance in China since the Late Qing Dynasty

Barbara Krug

ERS-2008-005-ORG

http://hdl.handle.net/1765/11287

Overoptimism among Founders: The Role of Information and Motivation

Ingrid Verheul and Martin Carree

ERS-2008-008-ORG

http://hdl.handle.net/1765/11557

Do Foreign Greenfields Outperform Foreign Acquisitions or Vice Versa? An Institutional Perspective Arjen H.L. Slangen and Jean-François Hennart ERS-2008-009-ORG

http://hdl.handle.net/1765/11558

Unemployment Benefits Crowd Out Nascent Entrepreneurial Activity

Philipp Koellinger and Maria Minniti

ERS-2008-012-ORG

http://hdl.handle.net/1765/11808

Acceleration of Technology Adoption within Firms: Empirical Evidence from the Diffusion of E-business Technologies Philipp Koellinger and Christian Schade

ERS-2008-013-ORG

http://hdl.handle.net/1765/11809

Belbin Revisited: The Construct Validity of the Interplace II Team Role Instrument

Dirk van Dierendonck and Rob Groen

ERS-2008-017-ORG

http://hdl.handle.net/1765/12123

China's Institutional Architecture: A New Institutional Economics and Organization Theory Perspective on the Links between Local Governance and Local Enterprises

Barbara Krug and Hans Hendrischke

ERS-2008-018-ORG

http://hdl.handle.net/1765/12191

Ethics Programs and Ethical Cultures: A Next Step in Unraveling their Multi-Faceted Relationship

Muel Kaptein

ERS-2008-020-ORG

http://hdl.handle.net/1765/12192

Entrepreneurship Education and Training in a Small Business Context: Insights from the Competence-based Approach Thomas Lans, Wim Hulsink, Herman Baert and Martin Mulder

ERS-2008-028-ORG

http://hdl.handle.net/1765/12466 
The Relationship between Technology, Innovation, and Firm Performance: Empirical Evidence on E-Business in Europe Philipp Koellinger

ERS-2008-031-ORG

http://hdl.handle.net/1765/12469

The Relationship between Ethical Culture and Unethical Behavior in Work Groups: Testing the Corporate Ethical Virtues Model

Muel Kaptein

ERS-2008-037-ORG

http://hdl.handle.net/1765/12783

Influence Costs in Agribusiness Cooperatives: Evidence from Case Studies

Constantine Iliopoulos and George Hendrikse

ERS-2008-040-ORG

http://hdl.handle.net/1765/12872

The Locus of Innovation in Small and Medium-sized Firms: The Importance of Social Capital and Networking in Innovative Entrepreneurship

Willem Hulsink, Tom Elfring and Wouter Stam

ERS-2008-041-ORG

http://hdl.handle.net/1765/12873

Stimulating Strategically Aligned Behaviour among Employees

Cees B. M. van Riel, Guido Berens and Majorie Dijkstra

ERS-2008-045-ORG

http://hdl.handle.net/1765/12903

Creating Strategic Aligned Behavior among Employees at Philips

Cees B.M. van Riel and Guido Berens

ERS-2008-046-ORG

http://hdl.handle.net/1765/13218

Why Identify? Self-Enhancement and Self-Consistency Motives in Organizational Identification

Mirdita N. Elstak, Cees B.M. van Riel and Michael G. Pratt

ERS-2008-047-ORG

http://hdl.handle.net/1765/13219

Science and Technology-based Regional Entrepreneurship in the Netherlands: Building Support Structures for Business

Creation and Growth Entrepreneurship

Willem Hulsink, Kashifa Suddle and Jolanda Hessels

ERS-2008-048-ORG

http://hdl.handle.net/1765/13220

I Can't Get No Satisfaction - Necessity Entrepreneurship and Procedural Utility

Joern Block and Philipp Koellinger

ERS-2008-051-ORG

http://hdl.handle.net/1765/13221

Financial Geographies and Emerging Markets in Europe

Bas Karreman

ERS-2008-054-ORG

http://hdl.handle.net/1765/13222

Entrepreneurship, Economic Growth and Policy in Emerging Economies

Roy Thurik

ERS-2008-060-ORG

http://hdl.handle.net/1765/13318 
License to Fail? How Leader Group Prototypicality Moderates the Effects of Leader Performance on Perceptions of Leadership Effectiveness

Steffen R. Giessner, Daan van Knippenberg, and Ed Sleebos

ERS-2008-066-ORG

http://hdl.handle.net/1765/13626

The Effect of Legal Families on the Development of Business Law in China: Who's Really Writing the Rules of the Game? Barbara Krug and Nathan Betancourt

ERS-2008-068-ORG

http://hdl.handle.net/1765/13764

Market Feedback and Team Commitment in Radical Product Innovation Process

Luca Berchicci and Christopher Tucci

ERS-2008-069-ORG

http://hdl.handle.net/1765/13765

The Strategic Determinants of Tardy Entry: Is Timeliness Next to Godliness?

Luca Berchicci, Andrew King, and Christopher Tucci

ERS-2008-070-ORG

http://hdl.handle.net/1765/13766

Businessman or Host? Individual Differences between Entrepreneurs and Small Business Owners in the Hospitality Industry Stephanie L. Wagener, Marjan J. Gorgievski, and Serge A. Rijsdijk

ERS-2008-073-ORG

http://hdl.handle.net/1765/13832

Understanding a Two-Sided Coin: Antecedents and Consequences of a Decomposed Product Advantage

Serge A. Rijsdijk, Fred Langerak, and Erik Jan Hultink

ERS-2008-074-ORG

http://hdl.handle.net/1765/13833

A Treatise on the Geographical Scale of Agglomeration Externalities and the Modifiable Areal Unit Problem Martijn J. Burger, Frank G. van Oort, and Bert van der Knaap

ERS-2008-076-ORG

http://hdl.handle.net/1765/13834

* A complete overview of the ERIM Report Series Research in Management: https://ep.eur.nl/handle/1765/1

ERIM Research Programs:

LIS Business Processes, Logistics and Information Systems

ORG Organizing for Performance

MKT Marketing

F\&A Finance and Accounting

STR Strategy and Entrepreneurship 